\title{
Ab initio and DFT studies of the interaction between carbonyl and thiocarbonyl groups: the role of $\mathrm{S} \ldots \mathrm{O}$ chalcogen bonds
}

\author{
Wiktor Zierkiewicz ${ }^{1}$ • Jindřich Fanfrlík ${ }^{2}$ - Pavel Hobza ${ }^{2,3} \cdot$ Danuta Michalska $^{1}$. \\ Thérèse Zeegers-Huyskens ${ }^{4}$
}

Received: 22 June 2016 / Accepted: 22 July 2016 / Published online: 12 August 2016

(C) The Author(s) 2016. This article is published with open access at Springerlink.com

\begin{abstract}
The chalcogen bonds formed between carbonyl bases $\left(\mathrm{H}_{2} \mathrm{C}=\mathrm{O}\right.$ and $\mathrm{CH}_{3^{-}}$and $\mathrm{Cl}$-derivatives) and carbon disulfide have been studied by density functional BLYP-D3 and ab initio $\operatorname{CCSD}(\mathrm{T})$ methods. The $\operatorname{CCSD}(\mathrm{T}) / \mathrm{CBS}$ calculated interaction energies between these molecules are moderate, ranging from -1.45 to $-2.29 \mathrm{kcal} \mathrm{mol}^{-1}$. The charge transfer occurs from the carbonyl base to $\mathrm{CS}_{2}$ and is small. According to the AIM analysis, the molecules are bonded by $\mathrm{S}$... O chalcogen bonds. In addition, weak van der Waals $\mathrm{S} \cdots \mathrm{Cl}$ and $\mathrm{S} \cdots \mathrm{H}$ interactions stabilize most of the systems. The same results can be extracted from the NBO calculations which reveal the nature of the interacting bonding and antibonding orbitals. For some of the carbonyl derivatives, other stable structures characterized by $\mathrm{S} \cdots \mathrm{Cl}$ bonds or $\mathrm{CH} \cdots \mathrm{C}$ hydrogen bonds are also predicted.
\end{abstract}

Electronic supplementary material The online version of this article (doi:10.1007/s00214-016-1972-z) contains supplementary material, which is available to authorized users.

Wiktor Zierkiewicz

Wiktor.Zierkiewicz@pwr.edu.pl

$\square$ Jindřich Fanfrlík

Fanfrlik@uochb.cas.cz

1 Faculty of Chemistry, Wrocław University of Technology, Wybrzeże Wyspiańskiego 27, 50-370 Wrocław, Poland

2 Gilead Sciences and IOCB Research Center, Institute of Organic Chemistry and Biochemistry (IOCB), Academy of Sciences of the Czech Republic, v.v.i., Flemingovo nám. 2, 16610 Prague 6, Czech Republic

3 Department of Physical Chemistry, Regional Center of Advanced Technologies and Materials, Palacký University, 77146 Olomouc, Czech Republic

4 Department of Chemistry, University of Leuven, 200F Celestijnenlaan, 3001 Heverlee, Belgium
A SAPT decomposition of the interaction energies allows to conclude that the electrostatic energy is the predominant component in the stronger complexes and that the dispersion energy becomes more important in the weaker van der Waals complexes.

Keywords Chalcogen bonds - Carbonyl and thiocarbonyl groups $\cdot \operatorname{CCSD}(\mathrm{T}) \cdot \mathrm{DFT}$

\section{Introduction}

An important class of noncovalent bonds is associated with the attraction between electronegative atoms. Depending on the nature of the bridging atoms [1-3], these interactions are commonly designed as halogen [4-9], chalcogen [10-16] or pnicogen [17-20] bonds. The attractive force has been attributed to an anisotropic distribution of electron density around the bridging $\mathrm{X}$ atom, characterized by a crown of positive electrostatic potential along the extension of the $\mathrm{Y}-\mathrm{X}$ bond $(\sigma$-hole $)$ or in areas perpendicular to it $(\pi$-hole) $[6-8,21,22]$. Let us remember that positive $\sigma$-holes often exist in conjugation with negative potentials in other portions of the atom surface; such atoms can interact electrostatically with both electrophiles and nucleophiles. The electrostatic interactions within these bonds are supplemented by charge transfer from the lone pair of the acceptor atom into the $\sigma^{*}$ or $\pi^{*} \mathrm{Y}-\mathrm{X}$ antibonding orbitals. The strength of the chalcogen bond depends on the properties of the $\sigma$-holes which can be characterized by their magnitude $\left(V_{\max }\right)$ and size [23]. In recent QM calculations, the remarkable ability of heteroboranes to form strong $\sigma$-hole interactions has been demonstrated [24, 25]. Phenyl-substituted thiaboranes have also been synthesized. The QM analysis of the crystal structure showed the dominant role 
of chalcogen bonding in the crystal packing of $2 \mathrm{D} / 3 \mathrm{D}$ aromatics [26].

In the present work, the interaction between substituted carbonyl derivatives and carbon disulfide or, in other words, the interaction between a carbonyl and a thiocarbonyl base is investigated by theoretical methods. Various substituents on the $\mathrm{C}=\mathrm{O}$ functional group $\left(\mathrm{CH}_{3}, \mathrm{H}, \mathrm{Cl}\right)$ are chosen in order to modulate the basicity of the carbonyls. It is important to mention that the $\mathrm{S}$...O interaction has attracted the biggest attention owing to its significance in the biological activity of some sulfur-containing compounds revealing enzymatic activity [27-29]. Iwaoka et al. $[30,31]$ suggested that the $\mathrm{S} \cdots \mathrm{O}=\mathrm{C}$ interactions control, to some extent, the protein folding and that these interactions depend on the nature of the carbonyl base involved $[31,32]$. The importance of orientation has been outlined as well [31].

The role of the $\pi^{*}(\mathrm{C}=\mathrm{S})$ antibonding orbitals has been discussed in several works. In the complex between $\mathrm{SO}_{2}$ and $\mathrm{H}_{2} \mathrm{C}=\mathrm{S}$, for example, a charge transfer from a $\mathrm{SO}_{2}$ oxygen lone pair to the $\pi *(\mathrm{C}=\mathrm{S})$ antibonding orbital of $\mathrm{H}_{2} \mathrm{C}=\mathrm{S}$ has been predicted [33]. The potential interactions of the nitrile halides $\mathrm{XNO}_{2}$ with $\mathrm{NH}_{3}$ as electron donor in the $\sigma$ - and $\pi$-hole regions have been investigated [34]. Let us notice that the interaction between carbon disulfide and $\mathrm{Cl}^{-}$, [35], HF [36], O, N, P, S bases [37], $\operatorname{HOX}(\mathrm{X}=\mathrm{F}, \mathrm{Cl}, \mathrm{Br})[38]$ has been investigated by theoretical methods.

To the best of our knowledge, the interaction between carbonyl derivatives and SCS has not been investigated nor theoretically, nor experimentally. This work presents a study of the structure and stabilities of these complexes. Detailed AIM and NBO analysis along with the SAPT results allows to discuss and compare the nature of the interaction in the different systems.

\section{Computational methods}

The optimized geometries, vibrational harmonic frequencies and infrared intensities were calculated for the following eight carbonyl bases: $\mathrm{H}_{2} \mathrm{C}=\mathrm{O} ; \mathrm{HClC}=\mathrm{O} ; \mathrm{Cl}_{2} \mathrm{C}=\mathrm{O}$; $\mathrm{Cl}_{3} \mathrm{CHC}=\mathrm{O} ; \mathrm{Cl}_{3} \mathrm{CClC}=\mathrm{O} ;\left(\mathrm{CCl}_{3}\right)_{2} \mathrm{C}=\mathrm{O} ; \mathrm{H}_{3} \mathrm{CHC}=\mathrm{O}$; and $\left(\mathrm{CH}_{3}\right)_{2} \mathrm{C}=\mathrm{O}$. Full geometry optimization and calculations of vibrational properties were performed for the complexes of these carbonyl bases with SCS. The BLYP-D3 method [39] with the Def2TZVPP basis set [40, 41] was used in the calculations.

The DFT interaction energies were corrected for the basis set superposition error (BSSE) computed by the CP method [42]. The $\operatorname{CCSD}(\mathrm{T})$ complete basis set limit (CBS) interaction energies of the studied complexes were determined using a previously described scheme [43]:
$\Delta \mathrm{E}^{\mathrm{CCSD}(\mathrm{T}) / \mathrm{CBS}}=\Delta \mathrm{E}_{\mathrm{CBS}}^{\mathrm{MP} 2}+\left(\Delta \mathrm{E}^{\mathrm{CCSD}(\mathrm{T})}-\Delta \mathrm{E}^{\mathrm{MP2} 2}\right)_{\text {aug-cc-pVDZ }}$ where $\Delta \mathrm{E}_{\mathrm{CBS}}^{\mathrm{MP} 2}$ was approximated by MP2F12/cc-pVQZF12 [44].

For the isolated molecules, the critical points on the electrostatic potential surface $\left(V_{\mathrm{s}, \max }\right.$ and $\left.V_{\mathrm{s}, \min }\right)$ were computed at the BLYP-D3/Def2TZVPP and HF/cc-pVDZ levels of theory using the WFA (wavefunction analysis) program [45].

A natural bond orbital (NBO) analysis provides a detailed insight into the charge transfer and the nature of the interacting orbitals in the molecular fragments. For isolated $\mathrm{CS}_{2}$ and for the studied complexes, a NRT (natural resonance theory) analysis has been performed in order to find all possible resonance structures of these systems. Subsequently, a NBO analysis has been performed for this electronic structure of the complex, which has the largest resonance weight. The atomic charges, occupation of orbitals and the second-order interaction energies were calculated by the DFT method using the 5.0 version of the NBO program [46, 47].

The atoms-in-molecules (AIM) analysis [48] was used in order to characterize the intermolecular interactions in the molecular systems investigated in this work. The presence of a AIM bond critical point (BCP) between the centers of the monomers in the complexes supports the presence of attractive bonding interactions. Molecular surface electrostatic potential (ESP) was calculated in the isolated molecules at the HF/cc-pVDZ and BLYP-D3/Def2TZVPP levels of theory.

For all the complexes, the symmetry-adapted perturbation theory (SAPT) decomposition of the interaction energies was performed at the MP2/cc-pVTZ level of theory. All the computations were carried out with the Gaussian 09 [49], MOLPRO 2012 [50], Turbomole 6.6 [51] and Cuby4 [52] programs.

\section{Results and discussion}

The formation of $\mathrm{S} \cdots \mathrm{O}$ chalcogen bonds is a common feature of all the systems investigated in this work and will be discussed in part A. Other stable structures depending on the substituents implanted on the carbonyl bond will be discussed in parts B and C.

\subsection{Chalcogen-bonded complexes}

\subsubsection{Structure and interaction energies}

Figure 1 illustrates the structure of the complexes optimized at the BLYP-D3/Def2TZVPP level. Small variations of intramolecular bond lengths such as small elongations of 

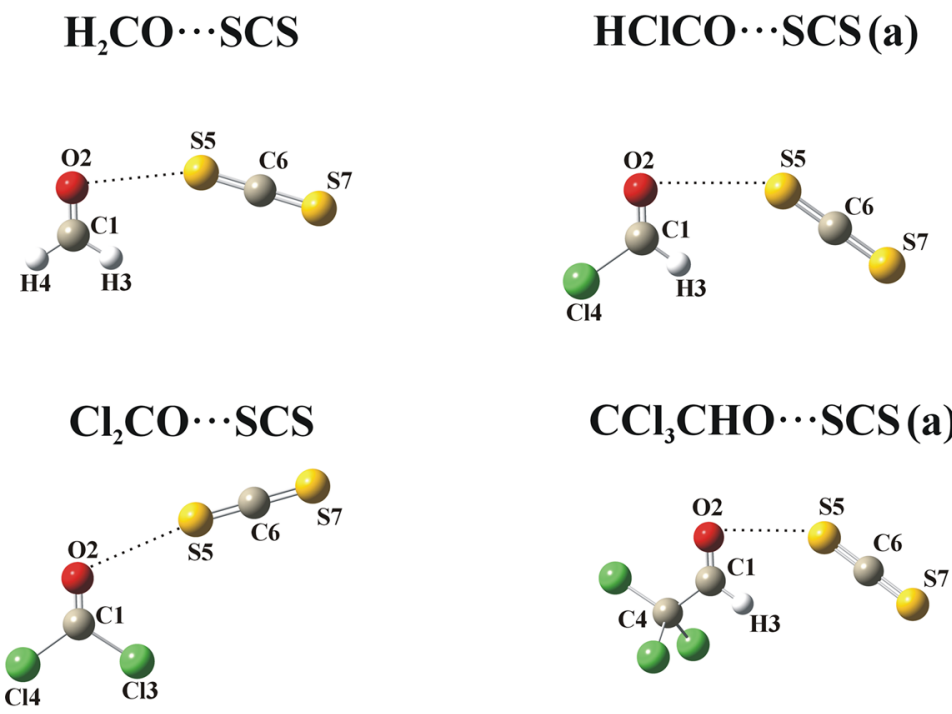

HCICO $\cdots$ SCS (b)
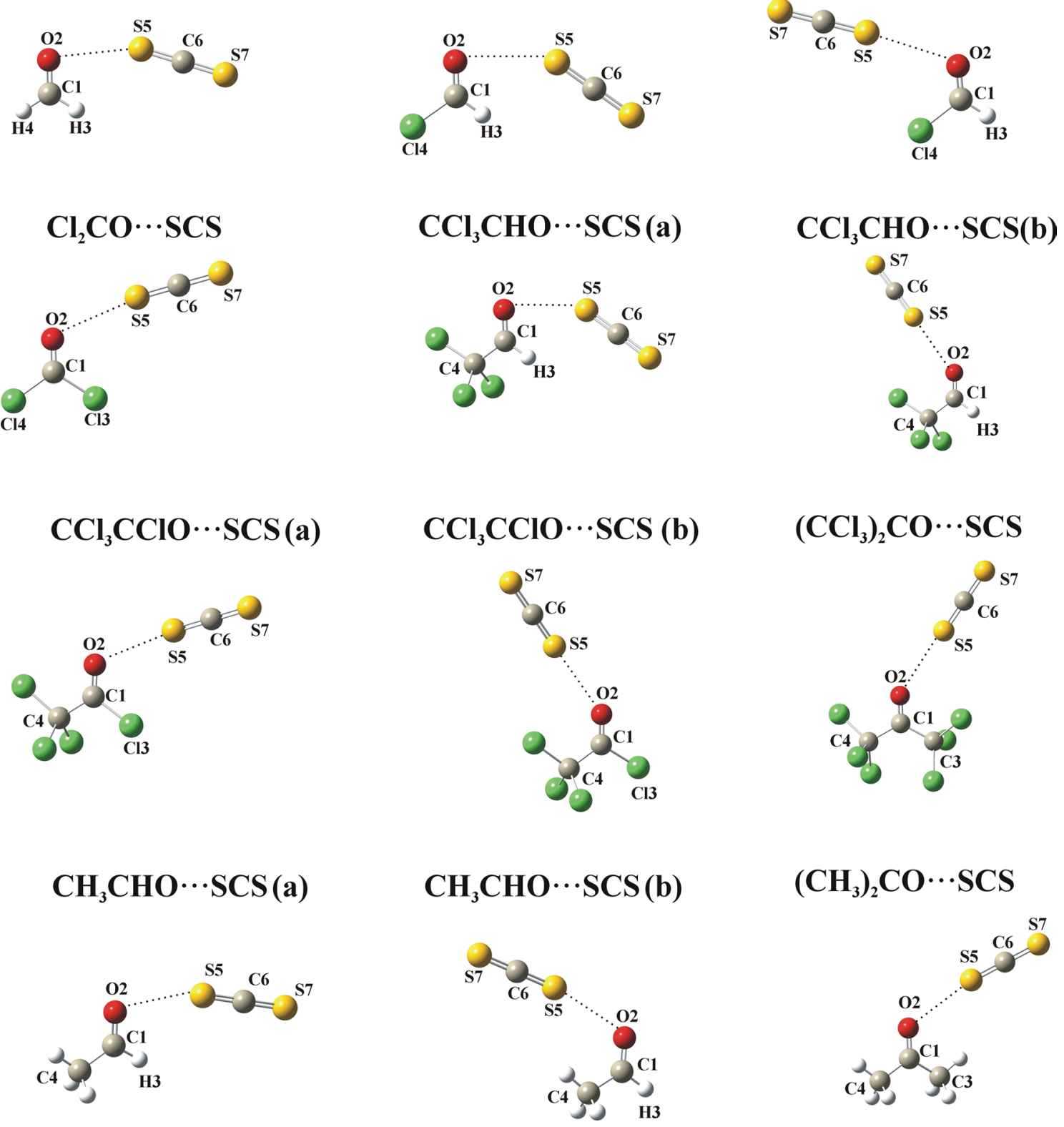

Fig. 1 Structures of the complexes between carbonyl bases and $\mathrm{CS}_{2}$ optimized at the BLYP-D3/Def2TZVPP level of theory

the $\mathrm{C}=\mathrm{O}$ bond lengths between 0.9 and $1.5 \mathrm{~m} \AA$ are predicted for the carbonyl derivatives. These variations will no more be discussed hereafter, our work being focused on the changes occurring in the SCS molecule. Selected intermolecular parameters are indicated in Table 1. The SCS bond remains almost linear, the largest deviations from linearity being equal to $0.16^{\circ}$.

The complexes between SCS and $\mathrm{CH}_{3} \mathrm{CHO}(\mathrm{a}, \mathrm{b})$ or $\left(\mathrm{CH}_{3}\right)_{2} \mathrm{CO}$ are characterized by intermolecular S $\cdots \mathrm{O}$ distances shorter than the sum on the van der Waals radii of $\mathrm{O}$ and $\mathrm{S}(3.32 \AA)$ and can be considered as typical $\mathrm{S} \cdots \mathrm{O}$ chalcogen bonds. In the $\mathrm{H}_{2} \mathrm{C}=\mathrm{S} \cdots \mathrm{O}_{2} \mathrm{~S}$ complex, a similar distance of $3.198 \AA$ has been predicted [33]. In contrast with the complexes between SCS and $\mathrm{Cl}^{-}$[35], $\mathrm{OH}_{2}$ [37] or $\mathrm{OHX}(\mathrm{X}=\mathrm{Cl}, \mathrm{Br})$ [38], in most of the systems investigated here, the $\mathrm{C}=\mathrm{S} \cdots \mathrm{O}$ bond is not linear. This can be accounted for by other interaction than the $\mathrm{S} \cdots \mathrm{O}$ ones in the molecular fragments. The $\mathrm{C} 1=\mathrm{O} 2$ and $\mathrm{S} 5=\mathrm{C} 6$ bonds are coplanar, except for the systems bearing a $\mathrm{CCl}_{3}$ group where the $\mathrm{C} 1-\mathrm{O} 2-\mathrm{S} 5-\mathrm{C} 6$ dihedral angle takes values between $5.7^{\circ}$ and $8.4^{\circ}$. It must be noticed that the $\mathrm{S} \cdots \mathrm{H}$ distances predicted between 3.094 and $3.184 \AA$ are larger than 
Table 1 Intermolecular parameters (distances in $\AA$, angles in degrees) in the complexes between substituted carbonyl bases and $\mathrm{CS}_{2}$ calculated at the BLYP-D3/ Def2TZVPP level of theory

\begin{tabular}{llclc}
\hline System & $\mathrm{R}(\mathrm{O} 2 \cdots \mathrm{S} 5)$ & $\angle \mathrm{C}=\mathrm{O} \cdots \mathrm{S} 5$ & $\mathrm{R}(\mathrm{S} 5 \cdots \mathrm{Y})^{\mathrm{a}}$ & $\angle \mathrm{C}-\mathrm{O} \cdots \mathrm{S} 5=\mathrm{C}$ \\
\hline $\mathrm{H}_{2} \mathrm{CO} \cdots \mathrm{SCS}$ & 3.322 & 95.7 & 3.180 & 0.3 \\
$\mathrm{HClCO} \cdots \mathrm{SCS}(\mathrm{a})$ & 3.488 & 88.1 & 3.129 & -0.3 \\
$\mathrm{HClCO} \cdots \mathrm{SCS}(\mathrm{b})$ & 3.412 & 114.5 & 3.954 & -3.3 \\
$\mathrm{Cl}_{2} \mathrm{CO} \cdots \mathrm{SCS}$ & 3.398 & 114.6 & 3.947 & 2.7 \\
$\mathrm{CCl}_{3} \mathrm{CHO} \cdots \mathrm{SCS}(\mathrm{a})$ & 3.418 & 90.0 & 3.094 & -1.3 \\
$\mathrm{CCl}_{3} \mathrm{CHO} \cdots \mathrm{SCS}(\mathrm{b})$ & 3.347 & 141.5 & 3.828 & 6.7 \\
$\mathrm{CCl}_{3} \mathrm{CClO} \cdots \mathrm{SCS}(\mathrm{a})$ & 3.385 & 116.3 & 3.948 & -8.4 \\
$\mathrm{CCl}_{3} \mathrm{CClO} \cdots \mathrm{SCS}(\mathrm{b})$ & 3.365 & 144.6 & 3.843 & -6.9 \\
$\left(\mathrm{CCl}_{3}\right)_{2} \mathrm{CO} \cdots \mathrm{SCS}$ & 3.384 & 145.0 & 3.815 & 5.7 \\
$\mathrm{CH}_{3} \mathrm{CHO} \cdots \mathrm{SCS}(\mathrm{a})$ & 3.273 & 97.9 & 3.184 & -0.1 \\
$\mathrm{CH}_{3} \mathrm{CHO} \cdots \mathrm{SCS}(\mathrm{b})$ & 3.280 & 119.3 & 3.160 & -1.8 \\
$\left(\mathrm{CH}_{3}\right)_{2} \mathrm{CO} \cdots \mathrm{SCS}$ & 3.236 & 122.5 & 3.159 & -4.8 \\
\hline
\end{tabular}

${ }^{a} \mathrm{Y}$ designs the atom in the closest position to $\mathrm{S} 5$, excluding the $\mathrm{O}$ atom $(\mathrm{Y}=\mathrm{H}$ or $\mathrm{Cl}$; see Fig. 1)
Table 2 Interaction energies $\left(\Delta E, \mathrm{kcal} \mathrm{mol}^{-1}\right)$ of carbonyl bases complexed with $\mathrm{CS}_{2}$ calculated at the CCSD(T)/CBS and BLYP-D3/ Def2TZVPP levels of theory

\begin{tabular}{lll}
\hline System & CCSD(T)/CBS & BLYP-D3/Def2TZVPP \\
\hline $\mathrm{H}_{2} \mathrm{CO} \cdots \mathrm{SCS}$ & -1.82 & $-1.56(0.26)^{\mathrm{a}}$ \\
$\mathrm{HClCO} \cdots \mathrm{SCS}(\mathrm{a})$ & -1.55 & $-1.37(0.19)$ \\
$\mathrm{HClCO} \cdots \mathrm{SCS}(\mathrm{b})$ & -1.45 & $-1.15(0.22)$ \\
$\mathrm{Cl}{ }_{2} \mathrm{CO} \cdots \mathrm{SCS}$ & -1.45 & $-1.16(0.19)$ \\
$\mathrm{CCl}_{3} \mathrm{CHO} \cdots \mathrm{SCS}(\mathrm{a})$ & -1.81 & $-1.60(0.20)$ \\
$\mathrm{CCl}_{3} \mathrm{CHO} \cdots \mathrm{SCS}(\mathrm{b})$ & -1.95 & $-1.51(0.25)$ \\
$\mathrm{CCl}_{3} \mathrm{CClO} \cdots \mathrm{SCS}(\mathrm{a})$ & -1.54 & $-1.24(0.20)$ \\
$\mathrm{CCl}_{3} \mathrm{CClO} \cdots \mathrm{SCS}(\mathrm{b})$ & -1.79 & $-1.35(0.19)$ \\
$\left(\mathrm{CCl}_{3}\right)_{2} \mathrm{CO} \cdots \mathrm{SCS}$ & -1.96 & $-1.55(0.22)$ \\
$\mathrm{CH}_{3} \mathrm{CHO} \cdots \mathrm{SCS}(\mathrm{a})$ & -2.11 & $-1.76(0.26)$ \\
$\mathrm{CH}_{3} \mathrm{CHO} \cdots \mathrm{SCS}(\mathrm{b})$ & -2.04 & $-1.72(0.29)$ \\
$\left(\mathrm{CH}_{3}\right)_{2} \mathrm{CO} \cdots \mathrm{SCS}$ & -2.29 & $-1.91(0.30)$ \\
\hline
\end{tabular}

a The BSSE corrections are indicated in parentheses

the sum of the van der Waals radii of $\mathrm{H}$ and $\mathrm{S}(3.00 \AA)$ and the $\mathrm{S} \cdots \mathrm{Cl}$ distances between 3.815 and $3.954 \AA$ are larger than the sum of van der Waals radii of O and S (3.55 $\AA$ ).

Table 2 reports the interaction energies calculated at the CCSD(T)/CBS and BLYP-D3/Def2TZVPP levels of theory. These results indicate that the interaction energies calculated at the $\operatorname{CCSD}(\mathrm{T}) \mathrm{CBS}$ level are moderate, ranging from -1.45 to $-2.29 \mathrm{kcal} \mathrm{mol}^{-1}$. They are approximately 10-20\% lower at the BLYP-D3 level. As expected, electron-withdrawing substituents $\left(\mathrm{Cl}, \mathrm{CCl}_{3}\right)$ decrease the interaction energies while the electron-donating substituent $\mathrm{CH}_{3}$ increases the interaction strength. It is interesting to mention here that the binding energies calculated at the MP2/6$31 \mathrm{G}$ level of $\left(\mathrm{CH}_{3}\right)_{2} \mathrm{~S}_{2}$ complexed with aliphatic ketones are of the same order of magnitude as those reported here [32].
Low binding energies were also reported for other SCS complexes, being $-1.15 \mathrm{kcal} \mathrm{mol}^{-1}$ for the SCS $\cdots \mathrm{OH}_{2}$ system (MP2/aug-cc-pVTZ level) [37] and $-1.50 \mathrm{kcal} \mathrm{mol}^{-1}$ for the SCS... OClH system [38]. The binding energy is much higher when SCS interacts with a strong electron donor such as $\mathrm{Cl}^{-}\left(-10.59 \mathrm{kcal} \mathrm{mol}^{-1}\right)$ [35].

\subsubsection{Electrostatic potential}

It is known that chalcogen atoms may have an electropositive region at its outermost end. This means that the $\mathrm{S}$ atom can interact with electron donors such as carbonyl bases. The electrostatic potential $\left(V_{\mathrm{s}, \mathrm{min}}\right)$ of isolated $\mathrm{CS}_{2}$ and some of the investigated carbonyl bases is illustrated in Fig. 2, and their values are reported in Table 3 .

The calculated $V_{\mathrm{s}, \max }$ for $\mathrm{CS}_{2}$ is $16.0 \mathrm{kcal} \mathrm{mol}^{-1}(\mathrm{HF} /$ cc-pVDZ level) and $14.3 \mathrm{kcal} / \mathrm{mol}^{-1}$ (BLYP-D3/Def2TZVPP). The $V_{\mathrm{s}, \min }$ located on the $\mathrm{S}$ atoms around the $\sigma$-hole calculated at this last level is $-1 \mathrm{kcal} \mathrm{mol}^{-1}$. These values are lower than the value of $17.9 \mathrm{kcal} \mathrm{mol}^{-1}\left(V_{\mathrm{s}, \max }\right)$ and $-2.2 \mathrm{kcal} \mathrm{mol}^{-1}\left(V_{\mathrm{s}, \mathrm{min}}\right)$ calculated at the MP2/augcc-pVTZ level [38]. Independently of the level of theory, these values are larger than those calculated for the majority of other sulfur-containing compounds. For example, $V_{\mathrm{s}, \max }$ of $\mathrm{F}_{2} \mathrm{C}=\mathrm{S}$ is $12.6 \mathrm{kcal} \mathrm{mol}^{-1}$. A larger value of $51.8 \mathrm{kcal} \mathrm{mol}{ }^{-1}$ is predicted for $\mathrm{SF}_{4}$. However, the $\mathrm{SF}_{4}$ complexes are stable only at low temperature.

The $V_{\mathrm{s}, \min }$ values of the carbonyl bases vary between -21.2 and $-42.2 \mathrm{kcal} \mathrm{mol}^{-1}$. This indicates that substitution of hydrogen atoms by $\mathrm{Cl}$ or $\mathrm{CCl}_{3}$ groups decreases the electrostatic potential while substitution by $\mathrm{CH}_{3}$ groups increases it.

The largest values of the $V_{\mathrm{s}, \mathrm{min}}$ are predicted for the strongest $\mathrm{H}_{2} \mathrm{C}=\mathrm{O} \cdots \mathrm{SCS}, \quad \mathrm{CH}_{3} \mathrm{CHO} \cdots \mathrm{SCS}$ and $\left(\mathrm{CH}_{3}\right)_{2} \mathrm{CO} \cdots \mathrm{SCS}$ complexes. For the other complexes, the 

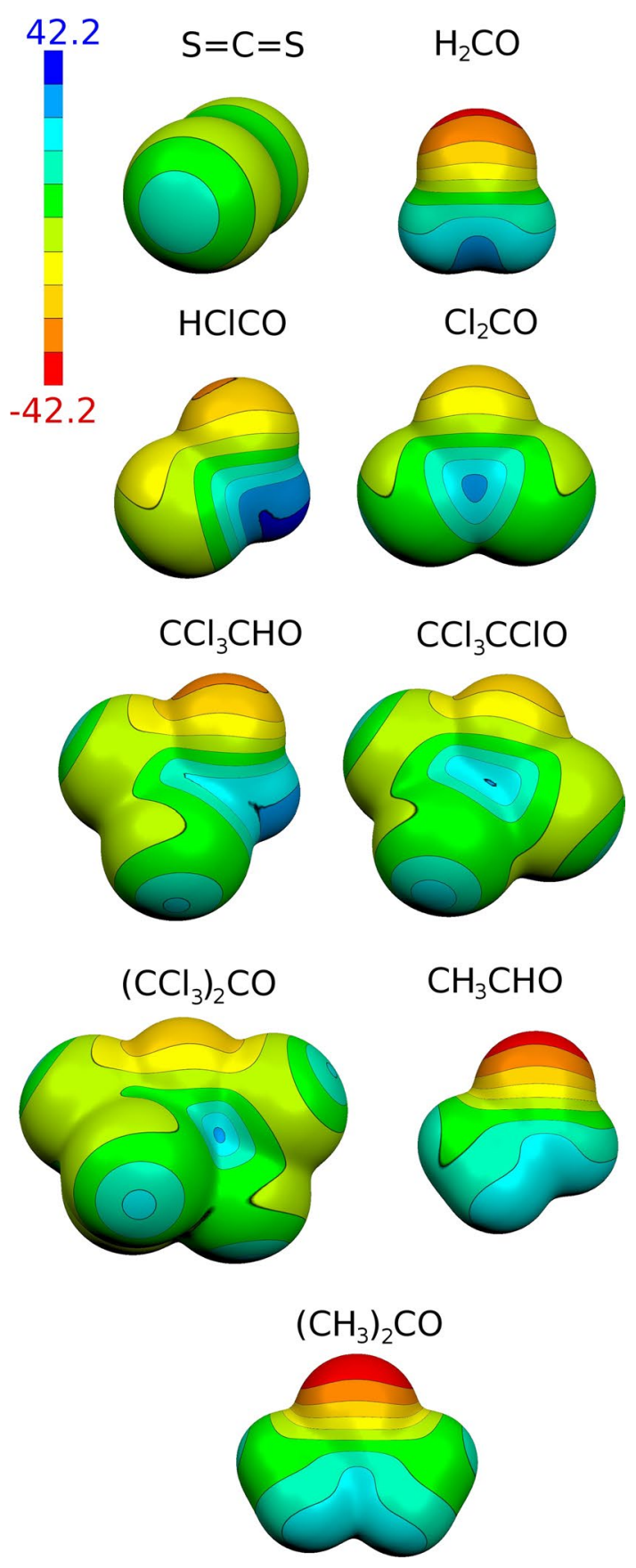

Fig. 2 Molecular surface of electrostatic potential (ESP, kcal/mol) of isolated SCS, $\mathrm{H}_{2} \mathrm{CO}, \mathrm{HClCO}, \mathrm{Cl}_{2} \mathrm{CO}, \mathrm{CCl}_{3} \mathrm{CHO}, \mathrm{CCl}_{3} \mathrm{CClO}$, $\left(\mathrm{CCl}_{3}\right)_{2} \mathrm{CO}, \mathrm{CH}_{3} \mathrm{CHO}$ and $\left(\mathrm{CH}_{3}\right)_{2} \mathrm{CO}$ computed on the 0.001 a.u. contour of the electrostatic density at the HF/cc-pVDZ level

stabilization energies are poorly correlated to the $\mathrm{V}_{\mathrm{s}, \min }$ values. As will be discussed in the next sections, this can be accounted for by the fact that the molecules are bonded together by other interactions than the $\mathrm{S} \cdots \mathrm{O}$ ones. The same remark also concerns the correlation between the interaction energies and the proton affinity (PA) of the carbonyl
Table 3 Electrostatic potentials $\mathrm{V}_{\mathrm{S} \text {,min }}$ (in $\mathrm{kcal} \mathrm{mol}{ }^{-1}$ ) on oxygen atoms for the isolated carbonyl bases calculated at the BLYP-D3/ Def2TZVPP level of theory

\begin{tabular}{lc}
\hline Molecule & $V_{\text {s,min }}$ \\
\hline $\mathrm{H}_{2} \mathrm{CO}$ & -28.1 \\
$\mathrm{HClCO}$ & -20.3 \\
$\mathrm{Cl}{ }_{2} \mathrm{CO}$ & -16.7 \\
$\mathrm{CCl}_{3} \mathrm{CHO}$ & -22.4 \\
$\mathrm{CCl}_{3} \mathrm{CClO}$ & -17.0 \\
$\left(\mathrm{CCl}_{3}\right)_{2} \mathrm{CO}$ & -18.7 \\
$\mathrm{CH}_{3} \mathrm{CHO}$ & -32.6 \\
$\left(\mathrm{CH}_{3}\right)_{2} \mathrm{CO}$ & -35.2 \\
\hline
\end{tabular}

derivatives, even when the attack angle of the incoming proton is considered. (The PAs are given in S.I. Table S.1.) It must be noticed that correlations between binding energies and PAs have been calculated for halogen bonds involving ethers $[53,54]$ or carbonyl derivatives [55, 56], but in these systems, only one interaction site was detected.

\subsubsection{AIM analysis}

According to the AIM theory, two atoms are interacting with each other if their nuclei are linked by a line of maximal density named the bond path. Figure 3 indicates the presence of a bond critical point $(\mathrm{BCP})$ in three selected complexes: $\mathrm{CH}_{3} \mathrm{CHO} \cdots \mathrm{SCS}(\mathrm{a}), \mathrm{CH}_{3} \mathrm{CHO} \cdots \mathrm{SCS}(\mathrm{b})$ and $\mathrm{CCl}_{3} \mathrm{CClO} \cdots \mathrm{SCS}(\mathrm{b})$. The electron density $(\rho)$, the Laplacian of electron density $\left(\nabla^{2} \rho\right)$ and the total electron energy $(\mathrm{H})$ at the BCP of the studied complexes are collected in Table 4.

These calculations indicate that the $\mathrm{H}_{2} \mathrm{CO} \cdots \mathrm{SCS}$ and $\mathrm{CH}_{3} \mathrm{CHO} \cdots \mathrm{SCS}(\mathrm{a})$ complexes are stabilized only by $\mathrm{S}$... O chalcogen bonds. In the case of the four complexes: HClCO $\cdots$ SCS(a), $\quad \mathrm{CCl}_{3} \mathrm{CHO} \cdots \mathrm{SCS}(\mathrm{a}), \mathrm{CH}_{3} \mathrm{CHO} \cdots \mathrm{SCS}(\mathrm{b})$ and $\left(\mathrm{CH}_{3}\right)_{2} \mathrm{CO} \cdots \mathrm{SCS}$, the AIM analysis reveals additional stabilization interactions between the sulfur and hydrogen atoms $(\mathrm{S} \cdots \mathrm{H})$. In the case of six other complexes: $\mathrm{HClCO} \cdots \mathrm{SCS}(\mathrm{b})$, $\mathrm{Cl}_{2} \mathrm{CO} \cdots \mathrm{SCS}, \quad \mathrm{CCl}_{3} \mathrm{CHO} \cdots \mathrm{SCS}(\mathrm{b}), \quad \mathrm{CCl}_{3} \mathrm{CClO} \cdots \mathrm{SCS}(\mathrm{a})$, $\mathrm{CCl}_{3} \mathrm{CClO} \cdots \mathrm{SCS}(\mathrm{b})$ and $\left(\mathrm{CCl}_{3}\right)_{2} \mathrm{CO} \cdots \mathrm{SCS}$, additional $\mathrm{S} \cdots \mathrm{Cl}$ interactions have been detected.

According to the Popelier's criteria for hydrogen bonds, the electron density at the $\mathrm{BCP}$ ranges from 0.002 to $0.035 \mathrm{au}$, and the Laplacian of the electron density ranges from 0.024 to 0.139 au $[57,58]$. As reported in Table 4, the $\mathrm{S} \cdots \mathrm{H}$ and $\mathrm{S} \cdots \mathrm{Cl}$ interactions do not fulfill the second criterion. Therefore, they cannot be classified as hydrogen or chalcogen bonds but as weak van der Waals interactions, in agreement with the corresponding intermolecular distances. It is worth mentioning that in all the complexes, except for 


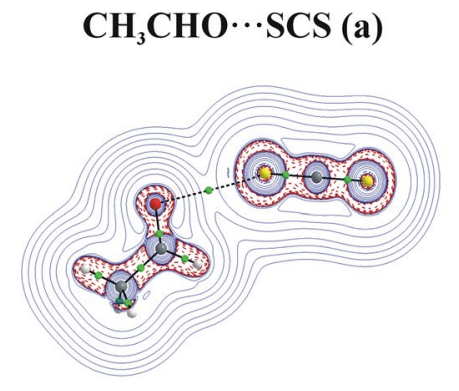

\section{$\mathrm{CH}_{3} \mathrm{CHO} \cdots \mathrm{SCS}(\mathrm{b}) \quad \mathrm{CCl}_{3} \mathrm{CClO} \cdots \mathrm{SCS}$}
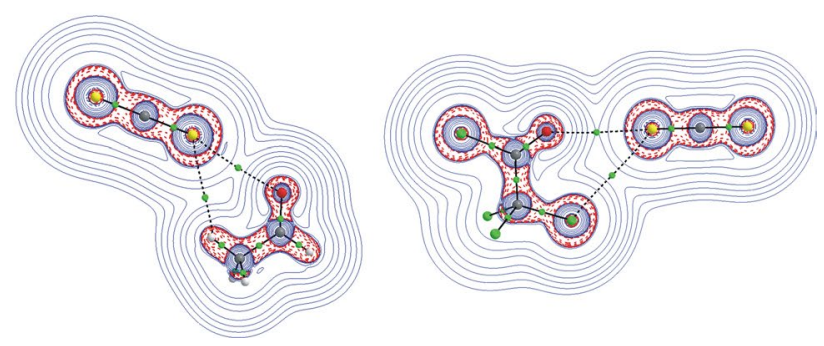

Fig. 3 Contour line diagram of the Laplacian of electron density of the $\mathrm{CH}_{3} \mathrm{CHO} \cdots \mathrm{SCS}(\mathrm{a}), \mathrm{CH}_{3} \mathrm{CHO} \cdots \mathrm{SCS}(\mathrm{b})$ and $\mathrm{CCl}_{3} \mathrm{CClO} \cdots \mathrm{SCS}$ complexes (in the plane passing through the $\mathrm{O}, \mathrm{S}$ and $\mathrm{H}$ or $\mathrm{Cl}$ atoms marked on the figure). The solid (blue) lines represent positive values

Table 4 Bond critical points (BCPs) properties: electron density $\rho$, Laplacian of electron density $\nabla^{2} \rho$ (both in atomic units) and total electron energy $\left(\mathrm{H}, \mathrm{kcal} \mathrm{mol}^{-1}\right)$. The electron density descriptions were obtained at the BLYP-D3/Def2TZVPP level

\begin{tabular}{lllll}
\hline System & Interaction & $\rho$ & $\nabla^{2} \rho$ & $\mathrm{H}$ \\
\hline $\mathrm{H}_{2} \mathrm{CO} \cdots \mathrm{SCS}$ & $\mathrm{S} \cdots \mathrm{O}$ & 0.0064 & 0.0234 & 0.861 \\
$\mathrm{HClCO} \cdots \mathrm{SCS}(\mathrm{a})$ & $\mathrm{S} \cdots \mathrm{O}$ & 0.0047 & 0.0179 & 0.707 \\
& $\mathrm{~S} \cdots \mathrm{H}$ & 0.0050 & 0.0165 & 0.560 \\
$\mathrm{HClCO} \cdots \mathrm{SCS}(\mathrm{b})$ & $\mathrm{S} \cdots \mathrm{O}$ & 0.0047 & 0.0181 & 0.748 \\
& $\mathrm{~S} \cdots \mathrm{Cl}$ & 0.0034 & 0.0101 & 0.420 \\
$\mathrm{Cl}_{2} \mathrm{CO} \cdots \mathrm{SCS}$ & $\mathrm{S} \cdots \mathrm{O}$ & 0.0048 & 0.0186 & 0.771 \\
& $\mathrm{~S} \cdots \mathrm{Cl}$ & 0.0034 & 0.0104 & 0.432 \\
$\mathrm{CCl}_{3} \mathrm{CHO} \cdots \mathrm{SCS}(\mathrm{a})$ & $\mathrm{S} \cdots \mathrm{O}$ & 0.0054 & 0.0202 & 0.770 \\
& $\mathrm{~S} \cdots \mathrm{H}$ & 0.0053 & 0.0175 & 0.577 \\
$\mathrm{CCl}_{3} \mathrm{CHO} \cdots \mathrm{SCS}(\mathrm{b})$ & $\mathrm{S} \cdots \mathrm{O}$ & 0.0050 & 0.0205 & 0.849 \\
& $\mathrm{~S} \cdots \mathrm{Cl}$ & 0.0041 & 0.0129 & 0.526 \\
$\mathrm{CCl}_{3} \mathrm{CClO} \cdots \mathrm{SCS}(\mathrm{a})$ & $\mathrm{S} \cdots \mathrm{O}$ & 0.0049 & 0.0191 & 0.788 \\
& $\mathrm{~S} \cdots \mathrm{Cl}$ & 0.0034 & 0.0103 & 0.430 \\
$\mathrm{CCl}_{3} \mathrm{CClO} \cdots \mathrm{SCS}(\mathrm{b})$ & $\mathrm{S} \cdots \mathrm{O}$ & 0.0046 & 0.0195 & 0.826 \\
& $\mathrm{~S} \cdots \mathrm{Cl}$ & 0.0040 & 0.0124 & 0.511 \\
$\left(\mathrm{CCl}_{3}\right)_{2} \mathrm{CO} \cdots \mathrm{SCS}$ & $\mathrm{S} \cdots \mathrm{O}$ & 0.0045 & 0.0188 & 0.795 \\
& $\mathrm{~S} \cdots \mathrm{Cl}$ & 0.0042 & 0.0132 & 0.538 \\
$\mathrm{CH}_{3} \mathrm{CHO} \cdots \mathrm{SCS}(\mathrm{a})$ & $\mathrm{S} \cdots \mathrm{O}$ & 0.0070 & 0.0256 & 0.924 \\
$\mathrm{CH}_{3} \mathrm{CHO} \cdots \mathrm{SCS}(\mathrm{b})$ & $\mathrm{S} \cdots \mathrm{O}$ & 0.0066 & 0.0243 & 0.908 \\
& $\mathrm{~S} \cdots \mathrm{H}$ & 0.0042 & 0.0126 & 0.468 \\
$\left(\mathrm{CH}_{3}\right)_{2} \mathrm{CO} \cdots \mathrm{SCS}$ & $\mathrm{S} \cdots \mathrm{O}$ & 0.0072 & 0.0266 & 0.970 \\
& $\mathrm{~S} \cdots \mathrm{H}$ & 0.0041 & 0.0127 & 0.470 \\
\hline & & & &
\end{tabular}

HClCO $\cdots$ SCS(a), the electron density $(\rho)$, the Laplacian of the electron density $\left(\nabla^{2} \rho\right)$ and the total electron energy $(\mathrm{H})$ at the $\mathrm{BCP}$ are larger for the $\mathrm{S} \cdots \mathrm{O}$ interaction than for the $\mathrm{S} \cdots \mathrm{H}$ and $\mathrm{S} \cdots \mathrm{Cl}$ interactions. For the $\mathrm{HClCO} \cdots \mathrm{SCS}(\mathrm{a})$ complex, the electron density for the $\mathrm{S} \cdots \mathrm{H}$ interaction is nearly equal to that characterizing the $\mathrm{S} \cdots \mathrm{O}$ interaction. For this complex, the $\mathrm{C}=\mathrm{O} \cdots \mathrm{S} 5$ angle $\left(88.1^{\circ}\right)$ is the smallest, of the Laplacian, while the dashed (red) lines represent the negative values. Small green points represent the bond critical points (BCPs). The electron density description was obtained at the BLYP-D3/ Def2TZVPP level

the $\mathrm{S} 5$ atom being perpendicular to the $\mathrm{C}=\mathrm{O}$ bond. It can be concluded from the AIM analysis that the $\mathrm{S}$...O chalcogen bond is the dominant stabilization interaction for most of the investigated complexes, but that additional van der Waals $\mathrm{S} \cdots \mathrm{Cl}$ or $\mathrm{S} \cdots \mathrm{H}$ interactions also contribute to the stability of the systems.

\subsubsection{NBO analysis}

Table 5 reports the charges on the $\mathrm{C}, \mathrm{S} 5$ and $\mathrm{S} 7$ atoms along with the charge transfer taking place from the carbonyl bases to $\mathrm{CS}_{2}$. The charges on these atoms calculated by different methods are given in S.I. Table S.3. Let us notice that the charge on the $\mathrm{C}$ atom in isolated $\mathrm{CS}_{2}$ calculated at the HF/aug-cc-PVTZ is -0.2739 e [38], much lower than the value of $-0.4506 \mathrm{e}$ obtained in the present work. The $\mathrm{S}$ and $\mathrm{C}$ atoms are characterized by the same electronegativity, and it may be rather surprising that our calculations predict in the isolated molecule large differences of charge on the $\mathrm{C}$ and $\mathrm{S}$ atoms. These differences can be accounted for by a large electronic delocalization within the molecule. Indeed, the NRT calculations show that in isolated $\mathrm{S} 5=\mathrm{C}=\mathrm{S} 7$ (having a resonance weight of $54.7 \%)$ there is a charge transfer from LP(1) S5 to $\sigma^{*}(\mathrm{C}=\mathrm{S} 7)$ and from $\mathrm{LP}(1) \mathrm{S} 7$ to $\sigma^{*}(\mathrm{C}=\mathrm{S} 5)$ as well as a charge transfer from $\mathrm{LP}(2) \mathrm{S} 5$ to $\pi^{*}(\mathrm{C}=\mathrm{S} 7)$ and from $\mathrm{LP}(2) \mathrm{S} 7$ to $\pi^{*}(\mathrm{C}=\mathrm{S} 5)$. This delocalization results in occupation of the $\sigma^{*}(\mathrm{C}=\mathrm{S})$ and $\pi^{*}(\mathrm{C}=\mathrm{S})$ orbitals equal to $0.0242 \mathrm{e}$ and $0.5259 \mathrm{e}$, respectively.

The results reported in Table 5 show that the charge transfer from the carbonyl base to $\mathrm{CS}_{2}$ is small, ranging from 0.4 to 6.3 me and does not follow the order of stability of the systems. There is a flow of electrons from the S5 atom to the external S7 atom.

It is interesting to compare the results obtained from the AIM analysis and the NBO calculations. The secondorder interaction energies are gathered in Table S.2 in S.I. 
Table 5 NBO charges on the C, S5 and S7 atoms (e) and charge transfer $(\mathrm{CT})$ from the carbonyl bases to $\mathrm{S} 5=\mathrm{C} 6=\mathrm{S} 7$ (me)

\begin{tabular}{lllll}
\hline System & $\mathrm{q}(\mathrm{C} 6)^{\mathrm{a}}$ & $\mathrm{q}(\mathrm{S} 5)^{\mathrm{a}}$ & $\mathrm{q}(\mathrm{S} 7)^{\mathrm{a}}$ & $\mathrm{CT}$ \\
\hline $\mathrm{H}_{2} \mathrm{CO} \cdots \mathrm{SCS}$ & -0.4570 & 0.2401 & 0.2136 & 3.4 \\
$\mathrm{HClCO} \cdots \mathrm{SCS}(\mathrm{a})$ & -0.4542 & 0.2238 & 0.2308 & 0.5 \\
$\mathrm{HClCO} \cdots \mathrm{SCS}(\mathrm{b})$ & -0.4556 & 0.2441 & 0.2070 & 4.5 \\
$\mathrm{Cl}{ }_{2} \mathrm{CO} \cdots \mathrm{SCS}$ & -0.4545 & 0.2382 & 0.2128 & 3.5 \\
$\mathrm{CCl}_{3} \mathrm{CHO} \cdots \mathrm{SCS}(\mathrm{a})$ & -0.4549 & 0.2308 & 0.2246 & 0.4 \\
$\left(\mathrm{CCl}_{3}\right) \mathrm{CHO} \cdots \mathrm{SCS}(\mathrm{b})$ & -0.4779 & 0.2481 & 0.2059 & 3.5 \\
$\left(\mathrm{CCl}_{3}\right) \mathrm{ClCO} \cdots \mathrm{SCS}(\mathrm{a})$ & -0.4546 & 0.2400 & 0.2112 & 3.5 \\
$\left(\mathrm{CCl}_{3}\right) \mathrm{ClCO} \cdots \mathrm{SCS}(\mathrm{b})$ & -0.4556 & 0.2416 & 0.2117 & 2.3 \\
$\left(\mathrm{CCl}_{3}\right)_{2} \mathrm{CO} \cdots \mathrm{SCS}$ & -0.4561 & 0.2446 & 0.2026 & 2.7 \\
$\mathrm{CH}_{3} \mathrm{CHO} \cdots \mathrm{SCS}(\mathrm{a})$ & -0.4582 & 0.2476 & 0.2066 & 4.0 \\
$\mathrm{CH}_{3} \mathrm{CHO} \cdots \mathrm{SCS}(\mathrm{b})$ & -0.4590 & 0.2490 & 0.2042 & 5.7 \\
$\left(\mathrm{CH}_{3}\right)_{2} \mathrm{CO} \cdots \mathrm{SCS}$ & -0.4506 & 0.2552 & 0.1991 & 6.3 \\
\hline
\end{tabular}

${ }^{a}$ In isolated SCS, $\mathrm{q}(\mathrm{C})=-0.4506 \mathrm{e}, \mathrm{q}(\mathrm{S})=0.2254 \mathrm{e}$

where $\mathrm{E}^{12}$ and $\mathrm{E}^{21}$ refer, respectively, to electronic donation from the carbonyl base to $\mathrm{CS}_{2}$ and in the reverse direction. Although the second-order energies are not strictly additive, these data indicate that in all the systems, except for $\mathrm{HClCO} \cdots \mathrm{CS}_{2}(\mathrm{a}), \mathrm{E}^{12}>\mathrm{E}^{21}$.

Both the AIM and NBO analyses reveal the existence of $\mathrm{S} 5 \cdots \mathrm{O}$ interactions and in some cases secondary S5 $\cdots \mathrm{Cl}$ or $\mathrm{Cl} \cdots \mathrm{H}$ interactions. Both methods reveal that the $\mathrm{S} 5 \cdots \mathrm{O}$ interaction is the stronger one, the $\mathrm{E}^{12}$ energies varying between 0.11 and $0.74 \mathrm{kcal} \mathrm{mol}^{-1}$. The only exception is the $\mathrm{HClCO} \cdots \mathrm{SCS}$ (a) complex where the charge transfer takes place to the S5 atom, resulting in a decrease in the positive charge on this atom (Table 5).

Both the AIM and NBO analyses indicate the presence of $\mathrm{S} \cdots \mathrm{Cl}$ interaction in the $\mathrm{HClO} \cdots \mathrm{SCS}(\mathrm{b}), \mathrm{Cl}_{2} \mathrm{CO} \cdots \mathrm{SCS}$, $\mathrm{CCl}_{3} \mathrm{CHO} \cdots \mathrm{SCS}(\mathrm{b}), \mathrm{CCl}_{3} \mathrm{ClO} \cdots \mathrm{SCS}(\mathrm{a}, \mathrm{b})$ systems and $\mathrm{S} \cdots \mathrm{H}$ interaction in the $\mathrm{HClCO} \cdots \mathrm{SCS}(\mathrm{b}), \mathrm{CCl}_{3} \mathrm{CHO} \cdots \mathrm{SCS}(\mathrm{a})$, $\mathrm{CH}_{3} \mathrm{CHO} \cdots \mathrm{SCS}(\mathrm{a}, \mathrm{b})$ and $\left(\mathrm{CH}_{3}\right)_{2} \cdots \mathrm{SCS}$ systems.

Let us also notice that the NBO analysis shows that $\mathrm{S} \cdots \mathrm{H}$ interactions detected by the AIM analysis can be extended to $\sigma^{*}(\mathrm{CC}), \sigma^{*}(\mathrm{CO})$ and $\sigma^{*}(\mathrm{CCl})$ orbitals. The weak $\mathrm{S} \cdots \mathrm{H}$ interaction in the $\mathrm{H}_{2} \mathrm{CO} \cdots \mathrm{SCS}$ and $\mathrm{CH}_{3} \mathrm{CHO} \cdots \mathrm{SCS}(\mathrm{a})$ systems was not predicted by the AIM calculations, in contrast with the NBO calculations. Some discrepancies between the AIM and NBO calculations have also been detected in the $\left(\mathrm{XNO}_{2}\right)_{2}$ homodimers [59].

It may be argued that the charge transfer and secondorder interaction energies are small (never exceeding 0.75 $\mathrm{kcal} \mathrm{mol}{ }^{-1}$ ) and not significant. However, in most of the systems, there is a good agreement between the AIM and NBO results, which suggests that these small values are relevant.

There are some discrepancies between the literature data concerning the variation of the $\mathrm{C}=\mathrm{S}$ distances resulting from the interaction with guest molecules. In the $\mathrm{SCS} \cdots \mathrm{Cl}^{-}$system, the bonded $\mathrm{C}=\mathrm{S}$ group contracts by $2.3 \mathrm{~m} \AA$ [35], while in the SCS ... OClH system, the bonded $\mathrm{C}=\mathrm{S}$ group elongates by $3 \mathrm{~m} \AA$ [38]. In the chalcogen bond formed between $\mathrm{Se}=\mathrm{C}=\mathrm{Se}$ and water, the elongation of the free $\mathrm{C}=\mathrm{Se}$ bond is larger $(3 \mathrm{~m} \AA)$ than the elongation of the bonded $\mathrm{C}=\mathrm{Se}$ group $(1 \mathrm{~m} \AA)$ but a reverse trend is predicted when $\mathrm{Se}=\mathrm{C}=\mathrm{Se}$ interacts with electron donors such as $\mathrm{PH}_{3}$ or $\mathrm{H}_{2} \mathrm{~S}$ [60]. These data indicate that the variation of the $\mathrm{C}=\mathrm{S}$ distances induced by the interaction with electron donors is small. This is also the case for the present systems. The variation of the $\mathrm{C}=\mathrm{S} 5$ and $\mathrm{C}=\mathrm{S} 7$ bond lengths is indicated in Table 6 which also reports for the strongest complexes the variation of the $\sigma^{*}(\mathrm{C}=\mathrm{S})$ and $\pi^{*}(\mathrm{C}=\mathrm{S})$ populations of both $\mathrm{C}=\mathrm{S}$ bonds.

It should be mentioned that a charge transfer from the LPs of the $\mathrm{Cl}^{-}$anion to the $\sigma^{*}(\mathrm{C}=\mathrm{S})$ and $\pi^{*}(\mathrm{C}=\mathrm{S})$ has been predicted for the $\mathrm{Cl}^{-} \ldots \mathrm{SCS}$ system, but the occupation of these antibonding orbitals has not been discussed [35].

These results show that the variations of the $\mathrm{C}=\mathrm{S} 5$ distances are very small; this is tentatively explained by the fact that the increase in the $\sigma^{*}(\mathrm{C}=5)$ population is nearly compensated by the decrease in the $\pi *(\mathrm{C}=5)$ population. In contrast, the increase in the $\mathrm{C}=\mathrm{S} 7$ distances is significant and may result from the increase in both the $\sigma^{*}(\mathrm{C}=\mathrm{S} 7)$ and $\pi *(\mathrm{C}=\mathrm{S} 7)$ populations.

\subsubsection{SAPT decomposition of the energies}

To evaluate the components of the interaction energies in the investigated complexes, a SAPT analysis has been
Table 6 Variation of the $\mathrm{C}=\mathrm{S} 5$ and $\mathrm{C}=\mathrm{S} 7$ distances $(\mathrm{m} \AA)^{\mathrm{a}}$ and corresponding $\sigma^{*}(\mathrm{C}=\mathrm{S})$ and corresponding $\sigma^{*}(\mathrm{C}=\mathrm{S})$ and $\pi^{*}(\mathrm{C}=\mathrm{S})$ populations $(\mathrm{me})^{\mathrm{b}}$

\begin{tabular}{llllllc}
\hline Systems & $\Delta r(\mathrm{C}=\mathrm{S} 5)$ & $\Delta \sigma^{*}(\mathrm{C}=\mathrm{S} 5)$ & $\Delta \pi^{*}(\mathrm{C}=\mathrm{S} 5)$ & $\Delta \mathrm{r}(\mathrm{C}=\mathrm{S} 7)$ & $\Delta \sigma^{*}(\mathrm{C}=\mathrm{S} 7)$ & $\Delta \pi^{*}(\mathrm{C}=\mathrm{S} 7)$ \\
\hline $\mathrm{H}_{2} \mathrm{CO} \cdots \mathrm{SCS}$ & 0.6 & 5.7 & -6.3 & 1.5 & 1.0 & 6.4 \\
$\mathrm{CH}_{3} \mathrm{CHO} \cdots \mathrm{SCS}(\mathrm{a})$ & 0.3 & 7.6 & -10.2 & 2.3 & 1.3 & 9.3 \\
$\mathrm{CH}_{3} \mathrm{CHO} \cdots \mathrm{SCS}(\mathrm{b})$ & 0.5 & 7.2 & -9.4 & 2.6 & 1.2 & 9.7 \\
$(\mathrm{CH} 3) 2 \mathrm{CO} \cdots \mathrm{SCS}$ & 0.3 & 7.4 & -11.6 & 3.2 & 1.4 & 12.3 \\
\hline
\end{tabular}

a $\mathrm{r}(\mathrm{C}=\mathrm{S})$ distance in isolated $\mathrm{S}=\mathrm{C}=\mathrm{S}$ is $1.5669 \AA$

${ }^{\mathrm{b}} \sigma^{*}(\mathrm{C}=\mathrm{S})$ occupation in isolated $\mathrm{S}=\mathrm{C}=\mathrm{S}$ is $0.0242 \mathrm{e} ; \pi^{*}(\mathrm{C}=\mathrm{S})$ occupation in isolated $\mathrm{S}=\mathrm{C}=\mathrm{S}$ is $0.5259 \mathrm{e}$ 
performed at the MP2/cc-pVTZ level of theory. The results are collected in Table 7.

The SAPT interaction energies are smaller than the $\operatorname{CCSD}(\mathrm{T})$ values and vary between -0.96 and $-1.92 \mathrm{kcal} \mathrm{mol}^{-1}$. These results indicate that the electrostatic term is the dominant attraction component, representing 51-52\% of the total energy for complexes characterized by typical S...O chalcogen bonds and between 39 and $46 \%$ for the systems involving chlorinated bases. In contrast, the dispersion energy represents $39-43 \%$ of the total energy for the stronger bases and increases to 48-56\% for the weaker bases. The induction effect is of the same order of magnitude in all the systems. The fact that dispersion forces contribute considerably to the bonding between chalcogen centers has been outlined in several dimethyl ether complexes [61, 62].

Table 7 SAPT (MP2/cc-pVTZ) interaction energies $\left(E_{\text {int }}\right.$, $\left.\mathrm{kcal} \mathrm{mol}^{-1}\right)$ and their components: electrostatic $E(\mathrm{elec})$, induction $E($ ind), dispersion $E$ (disp) and exchange $E$ (exch)

\begin{tabular}{|c|c|c|c|c|c|}
\hline System & $E_{\text {int }}$ & $E($ elec $)$ & $E$ (ind) & $E($ disp $)$ & $E(\mathrm{exch})$ \\
\hline $\mathrm{H}_{2} \mathrm{CO} \cdots \mathrm{SCS}$ & -1.42 & -1.68 & -0.21 & -1.35 & 1.82 \\
\hline $\mathrm{HClCO} \cdots \mathrm{SCS}(\mathrm{a})$ & -1.13 & -1.28 & -0.17 & -1.34 & 1.66 \\
\hline $\mathrm{HClCO} \cdots \mathrm{SCS}(\mathrm{b})$ & -1.02 & -1.06 & -0.13 & -1.26 & 1.43 \\
\hline $\mathrm{Cl}_{2} \mathrm{CO} \cdots \mathrm{SCS}$ & -0.96 & -1.00 & -0.09 & -1.34 & 1.46 \\
\hline $\mathrm{CCl}_{3} \mathrm{CHO} \cdots \mathrm{SCS}(\mathrm{a})$ & -1.29 & -1.45 & -0.16 & -1.59 & 1.90 \\
\hline $\mathrm{CCl}_{3} \mathrm{CHO} \cdots \mathrm{SCS}(\mathrm{b})$ & -1.42 & -1.40 & -0.18 & -1.62 & 1.78 \\
\hline $\mathrm{CCl}_{3} \mathrm{CClO} \cdots \mathrm{SCS}(\mathrm{a})$ & -1.06 & -1.00 & -0.10 & -1.42 & 1.46 \\
\hline $\mathrm{CCl}_{3} \mathrm{CClO} \cdots \mathrm{SCS}(\mathrm{b})$ & -1.27 & -1.13 & -0.11 & -1.59 & 1.56 \\
\hline$\left(\mathrm{CCl}_{3}\right)_{2} \mathrm{CO} \cdots \mathrm{SCS}$ & -1.39 & -1.18 & -0.13 & -1.70 & 1.62 \\
\hline $\mathrm{CH}_{3} \mathrm{CHO} \cdots \mathrm{SCS}(\mathrm{a})$ & -1.69 & -1.92 & -0.28 & -1.51 & 2.01 \\
\hline $\mathrm{CH}_{3} \mathrm{CHO} \cdots \mathrm{SCS}(\mathrm{b})$ & -1.68 & -2.05 & -0.33 & -1.62 & 2.31 \\
\hline$\left(\mathrm{CH}_{3}\right)_{2} \mathrm{CO} \cdots \mathrm{SCS}$ & -1.92 & -2.26 & -0.41 & -1.74 & 2.49 \\
\hline
\end{tabular}

Fig. 4 Structures of complexes between carbonyl bases and $\mathrm{CS}_{2}$ stabilized by $\mathrm{S}$... Cl interactions, optimized at the BLYP-D3/ Def2TZVPP level of theory

\subsection{Structures stabilized by $\mathrm{S}$... Cl interactions}

Other stable structures characterized by $\mathrm{S}$... Cl interactions have been predicted for chlorinated carbonyl bases, namely $\mathrm{Cl}_{2} \mathrm{CO}, \mathrm{CCl}_{3} \mathrm{ClCO}$ and $\left(\mathrm{CCl}_{3}\right)_{2} \mathrm{CO}$ interacting with $\mathrm{CS} 2$. The structures of these complexes are illustrated in Fig. 4.

In these structures, the $\mathrm{C}=\mathrm{O}$ group is not involved in the interaction. The shortest $\mathrm{Cl} \cdots \mathrm{S} 5$ distances are: $3.848,3.849$ and $3.767 \AA$ in the $\mathrm{Cl}_{2} \mathrm{CO} \cdots \mathrm{SCS}, \mathrm{CCl}_{3} \mathrm{ClCO} \cdots \mathrm{SCS}$ and $\left(\mathrm{CCl}_{3}\right)_{2} \mathrm{CO} \cdots \mathrm{SCS}$ complexes, respectively. These distances are longer than the sum of the van der Waals radii of $\mathrm{S}$ and $\mathrm{Cl}(3.55 \AA)$, indicating van der Waals interactions between these two atoms. The interaction energies are reported in Table 8. They are of the same order of magnitude as those calculated for the chalcogen-bonded complexes (Table 2). The NBO analysis indicates that in these complexes the charge transfer takes place from the carbonyl base to the $\mathrm{CS}_{2}$ molecule. The values of the $\mathrm{CT}$ are: $2.5,4.4$ and $5.8 \mathrm{me}$ in $\left(\mathrm{CCl}_{3}\right)_{2} \mathrm{CO} \cdots \mathrm{SCS}, \mathrm{Cl}_{2} \mathrm{CO} \cdots \mathrm{SCS}$ and $\mathrm{CCl}_{3} \mathrm{ClCO} \cdots \mathrm{SCS}$ complexes, respectively.

The SAPT decomposition of the interaction energies is indicated in Table 9. As follows from these data, the dominant attraction component is the dispersion energy which represents about $70 \%$ of the total attraction energy. The electrostatic component is equal to about $30 \%$ of the total energy. The contribution of the induction energy is negligibly small. These results are in line with the data predicted for carbonyl complexes. For these systems, it was indeed concluded that the dispersion component of the energy predominates in van der Waals complexes.

\subsection{Structures stabilized by $\mathrm{CH}$...C hydrogen bonds}

In the case of the four carbonyl bases bearing a $\mathrm{CH}$ group, other stable structures stabilized mainly by $\mathrm{C}-\mathrm{H} \cdots \mathrm{C}$ hydrogen bonds are also predicted by our calculations. It is
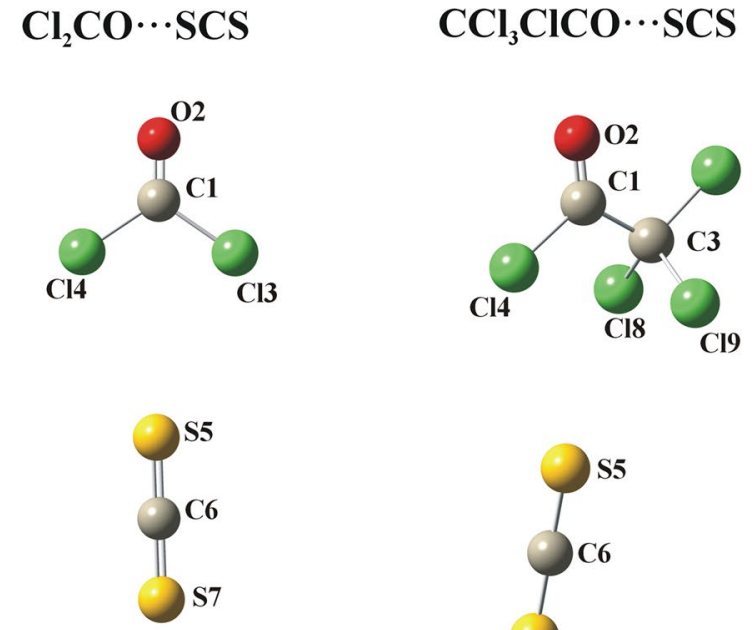

$\left(\mathrm{CCl}_{3}\right)_{2} \mathrm{CO} \cdots \mathrm{SCS}$
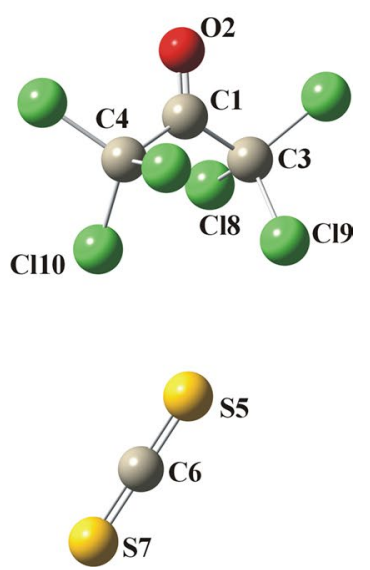
Table 8 Interaction energies $\left(\Delta E, \mathrm{kcal} \mathrm{mol}^{-1}\right)$ of $\mathrm{CS}_{2}$ complexes with carbonyl bases stabilized by $\mathrm{S} \cdots \mathrm{Cl}$ interactions

\begin{tabular}{lll}
\hline & $\Delta E$ & $\Delta E_{\text {corr }}$ \\
& $\mathrm{CCSD}(\mathrm{T})$ & BLYP-D3/Def2TZVPP \\
\hline $\mathrm{Cl}_{2} \mathrm{CO} \cdots \mathrm{SCS}$ & -1.27 & $-1.04(0.19)^{\mathrm{a}}$ \\
$\mathrm{CCl}_{3} \mathrm{CClO} \cdots \mathrm{SCS}$ & -1.90 & $-1.61(0.24)$ \\
$\left(\mathrm{CCl}_{3}\right)_{2} \mathrm{CO} \cdots \mathrm{SCS}$ & -2.17 & $-1.84(0.24)$ \\
\hline
\end{tabular}

${ }^{\text {a }}$ The values of BSSE corrections are in parentheses

Table 9 SAPT (MP2/cc-pVTZ) interaction energies $\left(E_{\text {int }}\right.$, $\left.\mathrm{kcal} \mathrm{mol}^{-1}\right)$ and their components: electrostatic $E(\mathrm{elec})$, induction $E($ ind), dispersion $E$ (disp) and exchange $E$ (exch) for the complexes investigated

\begin{tabular}{llllll}
\hline System & $E_{\text {int }}$ & $E($ elec $)$ & $E($ ind $)$ & $E($ disp $)$ & $E($ exch $)$ \\
\hline $\mathrm{Cl}_{2} \mathrm{CO} \cdots \mathrm{SCS}$ & -0.58 & -0.55 & -0.04 & -1.33 & 1.34 \\
$\mathrm{CCl}_{3} \mathrm{CClO} \cdots \mathrm{SCS}$ & -0.89 & -0.82 & -0.05 & -2.06 & 2.05 \\
$\left(\mathrm{CCl}_{3}\right)_{2} \mathrm{CO} \cdots \mathrm{SCS}$ & -1.03 & -1.1 & -0.06 & -2.36 & 2.49 \\
\hline
\end{tabular}

important to mention here that with proton donors such as $\mathrm{HF}$ [36] or OHX $(\mathrm{X}=\mathrm{Cl}, \mathrm{Br})$ [38], S $\cdots \mathrm{HF}$ or S $\cdots$ HO hydrogen bonds nearly perpendicular to the $\mathrm{S}$ atom are formed. Owing to the weaker acidity of the $\mathrm{CH}$ bonds of the carbonyl bases as compared with the HF or $\mathrm{OH}$ acidities, these structures were not predicted by our calculations. The formation of these $\mathrm{CH}$... C hydrogen bonds may find their origin in the large negative charge on the $\mathrm{C}$ atom $(\sim-0.45 \mathrm{e})$. Since the aim of this paper was mainly the discussion of the complexes stabilized by $\mathrm{S} \cdots \mathrm{O}$ chalcogen bonds, information on these complexes can be found in the S.I.

\section{Conclusions}

A theoretical study of interaction between carbonyl bases $\left(\mathrm{H}_{2} \mathrm{C}=\mathrm{O}\right.$ and $\mathrm{CH}_{3}$ - and $\mathrm{Cl}$-derivatives $)$ and $\mathrm{CS}_{2}$ has been carried out by means of DFT-BLYP-D3 and ab initio CCSD(T) methodologies. The main conclusions are the following:

1. The $\operatorname{CCSD}(\mathrm{T}) \mathrm{CBS}$ calculated interaction energies are moderate, ranging from -1.45 to $-2.29 \mathrm{kcal} \mathrm{mol}^{-1}$.

2. The electrostatic potential is very sensitive to the substituent implanted on the $\mathrm{C}=\mathrm{O}$ group and varies between $-21.2 \mathrm{kcal} \mathrm{mol}^{-1}$ (for $\mathrm{Cl}_{2} \mathrm{C}=\mathrm{O}$ ) and $-42.2 \mathrm{kcal} \mathrm{mol}^{-1}$ (for $\left(\mathrm{CH}_{3}\right)_{2} \mathrm{C}=\mathrm{O}$ ).

3. The charge transfer occurs from the carbonyl to the thiocarbonyl base and is small, ranging from 0.4 to $6.3 \mathrm{me}$.

4. The AMI analysis reveals the presence of a BCP between the $\mathrm{O}$ and $\mathrm{S}$ atoms. As shown by this analysis, the complexes are stabilized not only by $\mathrm{S}$...O chalco- gen bonds but also by weaker $\mathrm{S} \cdots \mathrm{Cl}$ or $\mathrm{S} \cdots \mathrm{H}$ interactions which are detected in most of the systems.

5. The results from NBO calculations provide further information on the nature of the bonding and antibonding orbitals and the second-order interaction energies.

6. The small variation of the $\mathrm{C}=\mathrm{S}$ distances is tentatively assigned to the variation in occupation of the $\sigma^{*}(\mathrm{C}=\mathrm{S})$ and $\pi *(\mathrm{C}=\mathrm{S})$ orbitals.

7. The SAPT decomposition of the interaction energies shows that in the stronger complexes, the electrostatic component of the energy predominates while in the weaker van der Waals complexes, the dispersion energy becomes predominant.

8. Other stable structures characterized by $\mathrm{S} \cdots \mathrm{Cl}$ interactions are predicted for the complexes between chlorinated ketones and $\mathrm{CS}_{2}$. In these structures, the $\mathrm{C}=\mathrm{O}$ group is not involved in the interaction, but the molecules are bonded together by two or three $\mathrm{S}$... Cl intermolecular bonds. These systems have about the same stability as the $\mathrm{C}=\mathrm{O} \cdots \mathrm{S}$ bonded systems.

9. Complexes between carbonyl bases bearing a $\mathrm{CH}$ group and $\mathrm{CS}_{2}$ are also stabilized by $\mathrm{CH}$... $\mathrm{C}$ hydrogen bonds. The interaction energies characterizing these systems are of the same order of magnitude as those predicted for the S $\cdots \mathrm{O}$ chalcogen bonds.

Acknowledgments This work was financed in part by a statutory activity subsidy from the Polish Ministry of Science and Higher Education for the Faculty of Chemistry of Wroclaw University of Technology as well as by research project RVO 61388963 of the Academy of Sciences of the Czech Republic. We acknowledge the financial support of the Czech Science Foundation (JF and PH: P208/12/G016). We also thank the Gilead Sciences and IOCB Research Center for financial support. A generous computer time from the Wroclaw Supercomputer and Networking Center as well as the Poznan Supercomputer and Networking Center is acknowledged. Th. Z. H. thanks the Department of Chemistry of the University of Leuven for computer facilities.

Open Access This article is distributed under the terms of the Creative Commons Attribution 4.0 International License (http://creativecommons.org/licenses/by/4.0/), which permits unrestricted use, distribution, and reproduction in any medium, provided you give appropriate credit to the original author(s) and the source, provide a link to the Creative Commons license, and indicate if changes were made.

\section{References}

1. Scheiner S (2011) A new noncovalent force: comparison of P...N interaction with hydrogen and halogen bonds. J Chem Phys 134:094315

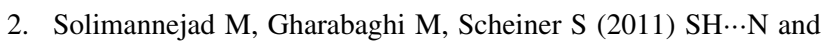
$\mathrm{SH} \cdots \mathrm{P}$ blue-shifting $\mathrm{H}$-bonds and $\mathrm{N} \cdots \mathrm{P}$ interactions in complexes pairing HSN with amines and phosphines. J Chem Phys 134:024312 
3. Zahn S, Frank R, Hey-Hawkins E, Kirchner B (2011) Pnicogen bonds: a new molecular linker? Chem Eur J 17:6034-6038

4. Lommersee JP, Stone AJ, Taylor R, Allen FH (1996) The nature and geometry of intermolecular interactions between halogens and oxygen or nitrogen. J Am Chem Soc 118:3108-3116

5. Metrangolo P, Resnati G (2008) Chemistry. Halogen versus hydrogen. Science 321:918-919

6. Politzer P, Murray JS, Concha MC (2007) Halogen bonding and the design of new materials: organic bromides, chlorides and perhaps even fluorides as donors. J Mol Mod 13:643-650

7. Politzer P, Murray JS, Clark T (2010) Halogen bonding: an electrostatically-driven highly directional noncovalent interaction. Phys Chem Chem Phys 28:7748-7757

8. Politzer P, Murray JS, Concha M (2008) Sigma-hole bonding between like atoms; a fallacy of atomic charges. J Mol Mod 14:659-665

9. Adhikari U, Scheiner S (2012) Sensitivity of pnicogen, chalcogen, halogen and $\mathrm{H}$-bonds to angular distortions. Chem Phys Lett 532:31-35

10. Werz DB, Gleiter R, Rominger F (1992) Computational studies of nonbonded sulfur-oxygen and selenium-oxygen interactions in the thiazole and selenazole nucleosides. J Am Chem Soc 114:2313-2320

11. Iwaoka M, Takamoto S, Tomoda S (2002) Statistical and theoretical investigations on the directionality of nonbonded $\mathrm{S} \cdots \mathrm{O}$ Interactions: implications for molecular design and protein engineering. J Am Chem Soc 124:10613-10629

12. Sanchez-Sanz G, Alkorta I, Elguero J (2011) Theoretical study of the HXYH dimers (X, Y $=\mathrm{O}, \mathrm{S}, \mathrm{Se})$. Hydrogen bonding and chalcogen-chalcogen interactions. Mol Phys 109:2543-2552

13. Jablonski M (2012) Energetic and geometrical evidence of nonbonding character of some intramolecular halogen $\cdots$ oxygen and other Y...Y interactions. J Phys Chem A 116:3753-3764

14. Adhikari U, Scheiner S (2013) Preferred configurations of peptide-peptide interactions. J Phys Chem A 117:489-496

15. Azofra $\mathrm{M}$, Scheiner S (2014) Complexes containing $\mathrm{CO}_{2}$ and $\mathrm{SO}_{2}$. Mixed dimers, trimers and tetramers. Phys Chem Chem Phys 16:5142-5149

16. Goettel JT, Chaudhary P, Hazendonk P, Mercier HPA, Gerken $\mathrm{M}(2012) \mathrm{SF}_{4} \cdot \mathrm{N}\left(\mathrm{C}_{2} \mathrm{H}_{5}\right)_{3}$ : the first conclusively characterized $\mathrm{SF}_{4}$ adduct with an organic base. Chem Comm 48:9120-9122

17. Bauza A, Mooibroek TJ, Frontera A (2015) The bright future of unconventional $\sigma / \pi$-hole interactions. Chem Phys Chem 16:2496-2517

18. Buhl M, Kilian P, Woollins JD (2011) Prediction of a new delocalised bonding motif between group 15 or group 16 atoms. Chem Phys Chem 12:2405-2408

19. Scheiner S (2013) The pnicogen bond: its relation to hydrogen, halogen and other noncovalent bonds. Acc Chem Res 46:280 288 (and references therein)

20. Sanchez-Sanz G, Trujillo C, Solimannejad M, Alkorta I, Elguero J (2013) Orthogonal interactions between nitryl derivatives and electron donors: pnicogen bonds. Phys Chem Chem Phys 15:14310-14318

21. Politzer P, Murray JS, Clark T (2013) Halogen bonding and other $\sigma$-hole interactions: a perspective. Phys Chem Chem Phys 13:11178-11189

22. Alkorta I, Sanchez-Sanz G, Elguero J, Del Bene JE (2012) Influence of hydrogen bonds on the P...P pnicogen bond. J Chem Theor Comput 8:2320-2327

23. Kolar M, Hostas J, Hobza P (2014) The strength and directionality of a halogen bond are co-determined by the magnitude and size of the $\sigma$-hole. Phys Chem Chem Phys 16:9987-9996

24. Pecina A, Lepsik M, Hnyk D, Hobza P, Fanfrlik J (2015) Chalcogen and pnicogen bonds in complexes of neutral icosahedral and bicapped square-antiprismatic heteroboranes. J Phys Chem A 119:1388-1395

25. Lo R, Fanfrlik J, Lepsik M, Hobza P (2015) The properties of substituted 3D-aromatic neutral carboranes: the potential for $\sigma$-hole bonding. Phys Chem Chem Phys 17:20814-20821

26. Fanfrlík J, Přáda A, Padělková Z, Pecina A, Macháček J, Lepšík M, Holub J, Růžička A, Hnyk D, Hobza P (2014) The dominant role of chalcogen bonding in the crystal packing of 2D/3D aromatics. Angew Chem Int Ed 53:10139-10142

27. Burling FT, Goldtein BM (1992) Computational studies of nonbonded sulfur-oxygen and selenium-oxygen interactions in the thiazole and selenazole nucleosides. J Am Chem Soc 114:2313-2320

28. Nagao Y, Hirata T, Goto S, Sano S, Kakehi A, Lizuka K, Shiro M (1998) Intramolecular nonbonded S ...O interaction recognized in (Acylimino)thiadiazoline derivatives as angiotensin II receptor antagonists and related compounds. J Am Chem Soc 120:3104-3110

29. Taylor JC, Markham GD (1999) The bifunctional active site of S-Adenosylmethionine synthetase. Roles of the active site aspartates. J Biol Chem 274:32909-32914

30. Iwaoka M, Takemoto S, Okada M, Tomoda s (2001) Statistical characterization of nonbonded $\mathrm{S} \ldots \mathrm{O}$ interactions in proteins. Chem Lett 19:132-133

31. Wu S, Greer A (2000) Attractive through-space S-O interaction in the DNA-cleaving antitumor antibiotic Leinamycin. J Org Chem 65:4883-4887

32. Iwaoka M, Takemoto S, Okada M, Tomoda S (2002) Statistical and theoretical investigations on the directionality of nonbonded $\mathrm{S}$.. O interactions. Implications for molecular design and protein engineering. J Am Chem Soc 124:10613-10620

33. Azofra LM, Scheiner S (2014) Complexation of $\mathrm{n} \mathrm{SO}$ molecules $(\mathrm{n}=1,2,3)$ with formaldehyde and thioformaldehyde. $\mathrm{J}$ Chem Phys 140:034302

34. Solimannejad M, Ramezani V, Trujillo C, Alkorta I, SanchezSanz G, Elguero J (2012) Competition and interplay between $\sigma$-hole and $\pi$-hole interactions: a computational study of $1: 1$ and 1:2 complexes of nitryl halides $\left(\mathrm{O}_{2} \mathrm{NX}\right)$ with ammonia. J Phys Chem A 116:5199-5206

35. Wang W, Ji B, Zhang Y (2009) Chalcogen bond: a sister noncovalent bond to halogen bond. J Phys Chem A 113:8132-8135

36. Li Q, Jing B, Liu Z, Li W, Cheng J, Gong B, Sun J (2010) Competition and cooperativity between hydrogen bond and $\sigma$-hole bond in SCS- $(\mathrm{HF})_{\mathrm{n}}(\mathrm{n}=1$ and 2 ) systems. J Mol Struct (Theochem) 952:90-95

37. Ramasami P, Ford TA (2014) Chalcogen-bonded complexes of some carbon dioxide analogues. J Mol Struct 1072:28-31

38. Li Q-Z, Li R, Guo R, Li H, Li W-Z, Cheng J-B (2012) Competition of chalcogen bond, halogen bond, and hydrogen bond in SCS-HOX and SeCSe-HOX (X = Cl and Br) complexes. Comput Theor Chem 980:56-61

39. Grimme S, Antony J, Ehrlich S, Krieg H (2010) A consistent and accurate ab initio parametrization of density functional dispersion correction (DFT-D) for the 94 elements H-Pu. J Chem Phys 132:154104

40. Weigend F, Ahlrichs R (2005) Balanced basis sets of split valence, triple zeta valence and quadruple zeta valence quality for $\mathrm{H}$ to $\mathrm{Rn}$ : design and assessment of accuracy. Phys Chem Chem Phys 7:3297-3305

41. Weigend $\mathrm{F}$ (2006) Accurate Coulomb-fitting basis sets for $\mathrm{H}$ to Rn. Phys Chem Chem Phys 8:1057-1065

42. Boys SF, Bernardi F (1970) The calculation of small molecular interactions by the differences of separate total energies. Some procedures with reduced errors. Mol Phys 19:553-566 
43. Jurecka P, Hobza $P$ (2002) On the convergence of the $\left(\Delta \mathrm{E}^{\mathrm{CCSD}(\mathrm{T})}-\Delta \mathrm{E}^{\mathrm{MP2}}\right)$ term for complexes with multiple H-bonds. Chem Phys Lett 365:89-94

44. Peterson KA, Adler TB, Werner HJ (2008) Systematically convergent basis sets for explicitly correlated wavefunctions: the atoms $\mathrm{H}, \mathrm{He}, \mathrm{B}-\mathrm{Ne}$, and Al-Ar. J Chem Phys 128:084102

45. Bulat FA, Toro-Labbe A, Brinck TE, Murray JS, Politzer P (2016) Quantitative analysis of molecular surfaces: areas, volumes, electrostatic potentials and average local ionization energies. J Mol Model 16:1679-1691

46. Reed AE, Curtiss LA, Weinhold F (1988) Intermolecular interactions from a natural bond orbital, donor-acceptor viewpoint. Chem Rev 88:899-926

47. Glendening ED, Badenhoop JK, Reed AE, Carpenter JE, Bohmann JA, Morales CM, Weinhold F (2001) NBO 5.0 Software (Theoretical Chemistry Institute, University of Wisconsin, Madison, WI). http://www.chem.wisc.edu/ nbo5

48. AIMAll (Version 14.11.23), Todd AK, TK Gristmill Software, Overland Park KS, USA, 2014 (aim.tkgristmill.com)

49. Frisch MJ, Trucks GW, Schlegel HB, Scuseria GE, Robb MA, Cheeseman JR, Scalmani G, Barone V, Mennucci B, Petersson GA, Nakatsuji H, Caricato M, Li X, Hratchian HP, Izmaylov AF, Bloino J, Zheng G, Sonnenberg JL, Hada M, Ehara M, Toyota K, Fukuda R, Hasegawa J, Ishida M, Nakajima T, Honda Y, Kitao O, Nakai H, Vreven T, Montgomery JA, Peralta JE, Ogliaro F, Bearpark M, Heyd JJ, Brothers E, Kudin KN, Staroverov VN, Kobayashi R, Normand J, Raghavachari K, Rendell A, Burant JC, Iyengar SS, Tomasi J, Cossi M, Rega N, Millam JM, Klene M, Knox JE, Cross JB, Bakken V, Adamo C, Jaramillo J, Gomperts R, Stratmann RE, Yazyev O, Austin AJ, Cammi R, Pomelli C, Ochterski JW, Martin RL, Morokuma K, Zakrzewski VG, Voth GA, Salvador P, Dannenberg JJ, Dapprich S, Daniels AD, Farkas Ö, Foresman JB, Ortiz JV, Cioslowski J, Fox DJ (2009) Gaussian 09, Revision E.0. Gaussian, Inc, Wallingford CT

50. Werner H-J, Knowles PJ, Knizia G, Manby FR, Schütz M, Celani P, Korona T, Lindh R, Mitrushenkov A, Rauhut G, Shamasundar KR, Adler TB, Amos RD, Bernhardsson A, Berning A, Cooper DL, Deegan MJO, Dobbyn AJ, Eckert F, Goll E, Hampel C, Hesselmann A, Hetzer G, Hrenar T, Jansen G, Köppl C, Liu Y, Lloyd AW, Mata RA, May AJ, McNicholas SJ, Meyer W, Mura ME, Nicklass A, O’Neill DP, Palmieri P, Peng D, Pflüger P, Pitzer R, Reiher M, Shiozaki T, Stoll H, Stone AJ, Tarroni R,
Thorsteinsson T, Wang M MOLPRO, version 2012.1, a package of ab initio programs

51. Ahlrichs R, Bar M, Haser M, Horn H, Kolmel C (1989) Electronic structure calculations on workstation computers: the program system turbomole. Chem Phys Lett 162:165-169

52. Rezac J (2016) Cuby: an integrative framework for computational chemistry. J Comput Chem 37:1230-1237

53. Sutradhar D, Chandra AK, Zeegers-Huyskens T (2014) A theoretical investigation of the interaction between fluorinated dimethyl ethers and molecular chlorine. Mol Phys 112:2791-2801

54. Sutradhar D, Chandra AK, Zeegers-Huyskens T (2016) Theoretical study of the interaction of fluorinated dimethyl ethers and the $\mathrm{ClF}$ and $\mathrm{HF}$ molecules. Comparison between halogen and hydrogen bonds. Int J Quantum Chem 116:670-680

55. Zierkiewicz W, Bienko D, Michalska D, Zeegers-Huyskens $\mathrm{T}$ (2015) Theoretical investigation of the halogen bonded complexes between carbonyl bases and molecular chlorine. J Comput Chem 36:821-832

56. Zierkiewicz W, Bienko D, Michalska D, Zeegers-Huyskens T (2015) On the nature of halogen bonded complexes between carbonyl bases and chlorotrifluoromethane. Theor Chem Acc 134:103

57. Koch U, Popelier PLA (1995) Characterization of C-H $\cdots \mathrm{O}$ hydrogen bonds on the basis of the charge density. J Phys Chem 99:9747-9754

58. Popelier PLA (1998) Characterization of a dihydrogen bond on the basis of the electron density. J Phys Chem A 102:1873-1878

59. Trujillo C, Sanchez-Sanz G, Alkorta I, Elguero J (2015) Halogen, chalcogen and pnicogen interactions in $\left(\mathrm{XNO}_{2}\right)_{2}$ homodimers (X = F, Cl, Br, I). New J Chem 39:6791-6802

60. Ramasami P, Ford AT (2015) Chalcogen-bonded complexes. Selenium-bound adducts of $\mathrm{NH}_{3}, \mathrm{H}_{2} \mathrm{O}, \mathrm{PH}_{3}$, and $\mathrm{H}_{2} \mathrm{~S}$ with OCSe, SCSe, and $\mathrm{CSe}_{2}$. J Mol Model 21:35

61. Bierholder Ch, Gieiter R, Werz DB, Köppel H (2007) Theoretical investigations on heteronuclear chalcogen-chalcogen interactions: on the nature of weak bonds between chalcogen centers. Inorg Chem 46:2249-2260

62. Bierholder C, Werz DB, Köppel H, Gieiter R (2006) Theoretical investigations on chalcogen-chalcogen interactions: what makes these nonbonded interactions bonding? J Am Chem Soc 128:2666-2674 